\title{
Measuring medical education environment in Bangladesh
}

Bangladesh is facing many challenges in health care that are similar to other developing countries. Challenges faced by medical education in Bangladesh are mainly pedagogical, structural and policy related. ${ }^{1-4}$ High population density, rapid urbanization, aging population, emigration of qualified health care personnel, changing disease pattern, financial constraints, corruption, and inefficiency constantly pressurizes an overburdened health care delivery system. This is compounded by a significant shortage and mal-distribution of qualified doctors in the country. It has to be ensured that the medical education meet the highest standards to keep pace with the changing needs of patients and the nation's health care system. In recent years many medical colleges have been established in Bangladesh in public (29), semi-public (6) and private (54) sectors, in total 89 , for undergraduate course leading to Bachelor of Medicine and Bachelor of Surgery (MBBS) degree in allopathic (modern) medicine. ${ }^{5}$ The situation poses the country's medical education environment vulnerable raising a question- 'Is the medical education environment in Bangladesh healthy?'

The medical educational environment is becoming increasingly the focus of research around the world and the literature detailing findings of this research is rapidly growing. ${ }^{6-7}$ The students in a medical institution apart from the formal and informal curriculum become aware of the environment of the education. Whereas the curriculum may remain the same, the environment may change from region to region, from one institution to the other and from academic year to another academic year. This climate of education can be stressed or relaxed, student-centered or teacher-centered, strict or lenient etc and moulds the students into its own. ${ }^{8-9}$

Hutchinson provides a good overview of Educational Environment ( $\mathrm{ABC}$ of learning and teaching in medicine. ${ }^{10}$ Others have also highlighted the importance of understanding the environment for effective management of the learning development and change within the health professions. ${ }^{11-12}$ Stimulated by their suggestions for action research, ${ }^{13}$ the 50-item Dundee Ready Education Environment Measure (DREEM) was developed as an instrument for measuring the Medical Education Environment of medical institutions by the Department of Medical Education at the Dundee University Medical College in Dundee, Scotland. ${ }^{14}$ They used a panel of 100 medical educators from around the world. The inventory was validated by over 1000 students world-wide and is now being used widely in order to measure and 'diagnose' undergraduate educational climates in the health professions, having been translated into different languages and is currently being used in many countries. ${ }^{15-16}$ The DREEM gives a global score (out of 200) for the 50 items, and has five sub-scales relating to Students' Perceptions of Learning; Students Perceptions of Teachers; Students' Academic Self-Perceptions; Students' Perceptions of Atmosphere; Students' Social Self-Perceptions. It has a consistently high reliability and data can be collected and analyzed according to variables such as year of study; gender; courses/attachments. 
Since its inception it has proven to be a valuable instrument, that has been found to be multicultural and generic with consistent reliability and has been invaluable in studies conducted worldwide in profiling the strengths and weaknesses of institutions against a range of variables, including gender, age, course level, mode of entry, ethnicity, learning styles, grade point averages, teaching methodologies, etc. ${ }^{3}$

In Bangladesh, Directorate General Health Services under the Ministry of Health and Family Welfare, Bangladesh, a university and Bangladesh Medical \& Dental Council jointly responsible for regulating Medical Education given by the above mentioned public, semi-public and private medical colleges. Studies are needed to measure the educational environment in these institutions. This should allow the stakeholders to take steps in enhancing the environment in order to improve the quality of its product i.e. the medical graduates.

\section{MS Laskar}

Professor

Department of Community Medicine

Gazi Medical College

Khulna, Bangladesh

\section{References}

1. Amin Z, Merrylees N, Hanif A, Talukder MHK. Medical education in Bangladesh. Medical Teacher 2008;30:243-7.

2. Amin Z, Samarasekera DD, Eng KH. A compelling call for quality in medical education. J Bangladesh Coll Phys Surg 2007;25:6-7.

3. Majumder MA. A review of undergraduate medical curriculum. Bangladesh Med J 2002;34:47-50.
4. Majumder MAA, Souza U, Rahman S. Trends in medical education: challenges and directions for need-based reforms of medical training in Southeast Asia. Int J Med Sci 2004;58:369-80.

5. List of medical colleges in Bangladesh. h t t p://en.wikipedia.org/wiki/ List_of_medical_colleges_in_Bangladesh (Accessed on January 30, 2015).

6. Roff S. Education Environment: a Bibliography. Medical Teacher 2005;27(4):353-7.

7. Roff S. The Dundee Ready Educational Environment Measure (DREEM)- a generic instrument for measuring students' perceptions of undergraduate health professions curricula. Medical Teacher 2005;27(4):322-5.

8. Roff $\mathrm{S}$, McAleer $\mathrm{S}$. What is Educational Climate? Medical Teacher 2001;23(4): 333-4.

9. Gazi EA, Laskar MS. Art of lecture in medical education. Bang Med J Khulna 2013;46:24-7.

10. Hutchinson L. ABC of learning and teaching educational environment. BMJ 2003;326:810-2.

11. Genn JM. AMEE Medical Education Guide No.23 (Part 1): Curriculum, environment, climate, quality and change in medical education- a unifying perspective. Medical Teacher 2001;23(4):337-44.

12. Harden RM. The learning environment and the curriculum. Medical Teacher 2001;23:335-6.

13. Genn JM, Harden RM. What is medical education here really like?: Suggestions for action research studies of climates of medical education environments. Medical Teacher 1986;8(2):111-24. 


\section{Mediscope}

\section{The Journal of GMC}

14. Roff S, McAleer S, Harden RM, et al. comparing Nigeria and Nepal. Medical Development and validation of the Teacher 2001;23(4):378-82. Dundee Ready Education Environment Measure (DREEM). Medical Teacher 1997;19(4):295-9.

15. Roff S, McAleer S, Ifere OS, Bhattacharya S. A global diagnostic tool for measuring educational environment:

16. Khan J, Tabasum S, Yousafzai UK, Mukhtar O. Measuring the medical education environment in undergraduate medical colleges across Panjab, Pakistan. Biomedica 2011;27:14-8. 